\title{
Analysis and Research on the current situation of Jiaodong traditional marine folk culture in cultural tourism products
}

\author{
Peng $\mathrm{Han}^{1}$, Junsheng $\mathrm{Yu}^{1}$ and Ziqian Wang, ${ }^{1,}$ \\ ${ }^{1}$ College of art, Qingdao Huanghai University, 266427 West Coast new area, Qingdao, Shandong, China
}

\begin{abstract}
In recent years, the traditional folk culture as the core of the tourism, culture industry and derivative industry has driven the development of regional economies in Jiaodong. How to develop and utilize the traditional folk culture resources in the region, make them into folk culture tourism products and bring economic benefits have become a new research topic in related fields. This paper takes Jiaodong traditional folk culture as a starting point, folk culture tourism products as the research object, from the practical, creative, cultural, historical and service design point of view, analysing Jiaodong traditional folk culture in folk culture and tourism products in the current situation and its defects, and provides ideas for the sustainable development of Jiaodong traditional folk culture in folk culture and tourism products.
\end{abstract}

\section{Perface}

"Cultural travel products" bear the culture and connotation of history. through the designer's interpretation and reconstruction of historical relics, traditional culture and technology, the connotation of traditional culture and modern product design techniques are combined to create a modern aesthetic and in line with the traditional cultural connotation of the product. Since the end of the last century, the western developed countries have taken cultural and creative industries as an important measure of economic development, and after many years of development has become the pillar industry of these countries. China's cultural and creative industry started late, but it has sufficient development potential. It plays an important role in the development planning of many regions by mining historical and cultural resources to drive regional economic growth. With the improvement of people's living standards and traditional culture in recent years, the revival of folk tours, cultural tours, and the number of people continue to increase, driving the tourism economy continued to rise. Therefore, how to develop tourism and local folk culture more effectively, so that tourists can feel the cultural atmosphere of the tourist destination at the same time of leisure has become a common problem in related fields. In this paper, the traditional folk customs of Jiaodong as the starting point, folk culture and tourism products as the research. From the perspective of practicality, creativity, culture, history and service design, the object of this paper is to analyse the current situation and defects of the traditional folk customs in the cultural tourism products, and provides ideas for the sustainable development of the traditional folk customs in the cultural and tourism products. ${ }^{[1]}$

\section{The Historical Evolution of Jiaodong Folk Culture}

Jiaodong Peninsula is located at the easternmost tip of Shandong, China. The Emperors of Qin and Han Dynasty came here to watch the sea. The life characteristics of living by the sea have formed different marine folk culture. Traditional folk culture, as a life habit formed by humans for a long time, gradually accompanied the spiritual and material form of human history. However, with the rapid development of economy and society, modern concepts, ideas, technology, products, etc. have flooded our lives. While these are improving people's lives, some traditional customs are gradually replaced by products of modern technology, and the speed of their disappearance is surprising. Each item of traditional folklore contains the cultural connotation of a nation and a region in a specific period, so the research and protection of traditional folklore cannot be delayed. ${ }^{[2]}$

The three sides of the Jiaodong area are ringed by the sea, and its unique marine folk customs are numerous, which can be summarized as: marine human customs, rural homes and tools, mountain and sea farming, folk crafts, fun and leisure five aspects, reflecting the traditional folk customs and traditional folk tools changes in the Jiaodong region, showing the customs and customs of the Jiaodong region and the hard-working wisdom of the local people.

\section{Analysis of The Current Situation and Problems of Jiaodong Folk Culture Tou rism Products}

With the continuous development of folk culture and

\footnotetext{
* Corresponding author: ziqianwang0728@168.com
} 
tourism, how to revive and develop Jiaodong folk culture and tourism products, and how to express the connotation of human customs and farming in Jiaodong folk culture and tourism products through innovative, artistic and visual design techniques, How to promote Jiaodong folk culture and cultural tourism products as local brands by the government and relevant enterprises and institutions needs us to explore. To solve the above problems, we can start from the existing folk cultural tourism products, analyze the existing products, and rectify or improve the problems.

\subsection{Classification of Jiaodong folk culture and tourism products}

"Folk culture and tourism products" refers to the hardware carrier with the local folk culture implication produced by a series of design methods based on the tourism location and the local traditional folk culture and crafts. Jiaodong folk culture and tourism products are designed with the local cultural implication by taking Jiaodong's cultural customs, rural houses, farming and animal husbandry as creative elements. This is not only related to but also different from the general tourist souvenirs with local characteristics. According to the previous research, Jiaodong folk cultural and creative products are classified according to their characteristics (Table 1).

Table1. classification and characteristics of Jiaodong civilian tour products

\begin{tabular}{|c|c|c|c|}
\hline Category & $\begin{array}{c}\text { Folk culture and tourism } \\
\text { products }\end{array}$ & Folk elements & Basic characteristics \\
\hline $\begin{array}{c}\text { Stationery } \\
\text { Products }\end{array}$ & $\begin{array}{c}\text { Pen, book, schoolbag, tape, } \\
\text { bookmark, etc }\end{array}$ & Confucian culture & $\begin{array}{c}\text { Educational, combined, functional and } \\
\text { artistic }\end{array}$ \\
\hline $\begin{array}{c}\text { Daily } \\
\text { necessities }\end{array}$ & $\begin{array}{c}\text { water cups, Hand-made Soap, } \\
\text { hats, clothing, Keychains, } \\
\text { eye masks, etc }\end{array}$ & $\begin{array}{c}\text { Traditional architectural } \\
\text { design; Q version of folk } \\
\text { patterns; Traditional characters }\end{array}$ & $\begin{array}{c}\text { Practicality, individuality, decoration, } \\
\text { artistry and culture }\end{array}$ \\
\hline $\begin{array}{c}\text { Decorative } \\
\text { articles }\end{array}$ & $\begin{array}{c}\text { Ornaments, mobile phone } \\
\text { case, mobile phone case, } \\
\text { necklace, bracelet, etc } \\
\text { patterns; Traditional characters } \\
\text { Entertainme } \\
\text { nt products }\end{array}$ & $\begin{array}{c}\text { Traditional architectural } \\
\text { Toys, lanterns, etc }\end{array}$ & Artistic, aesthetic, decorative and cultural \\
\hline Snacks & $\begin{array}{c}\text { Three fresh potstickers, } \\
\text { thousand layer cake, }\end{array}$ & Special snack & Entertainment, art and culture \\
\hline
\end{tabular}

\subsection{Analysis on the problems of Jiaodong folk culture and tourism products}

The data of this paper comes from the field survey. 200 questionnaires were randomly distributed in traditional folk scenic spots and other places, and 193 valid questionnaires were finally collected (Table 2). The respondents included local residents $(23.2 \%)$, merchants (30.4\%) and tourists (46.4\%).

Through visiting and investigating the folk custom museum and other related scenic spots in Jiaodong, it is found that the sales of folk custom cultural tourism products in the scenic spots are not optimistic. During the investigation of the interviewees, it is found that about $70 \%$ of the interviewees have a strong interest in folk custom cultural tourism products, and only about $26 \%$ want to buy them. Most of the interviewees only stay in the browsing stage, and the buyers are only limited to buying decorative products or special products The color snacks. In addition, from the survey data, it can be found that the respondents are mainly interested in traditional folk culture, handicrafts, folk snacks and other aspects. However, in the interviews, it is found that there are many cheap commodity distribution centers around most folk scenic spots, which lowers the image of folk products. At the same time, we also found some problems in the folk cultural tourism products.

\subsubsection{The culture of products is not strong}

Cultural tourism product" is to use the symbolic meaning, aesthetic characteristics, humanistic spirit and cultural elements of the original works of art to interpret and reconstruct the original works of art. Through the designer's own understanding of culture, the cultural elements of the original works of art are combined with the creativity of the product itself to form a new type of cultural tourism product. ${ }^{[3]}$ At present, most of the folk cultural tourism products in Jiaodong area only extract elements from the original art or culture, and directly copy the extracted elements on some existing products, without interpreting, reconstructing and redesigning the original works of art or culture. Some cultural and tourism products with good cultural performance can provide design ideas and ideas for the development of folk culture and tourism products in Jiaodong, such as the "high mountains and flowing water" fragrant plug designed by Beijing LKK design company, as shown in Fig.1. The product extracts elements from the architectural appearance of the National Grand Theater for reconstruction and redesigned. It combines the traditional Chinese cultural image of high mountains and flowing water to find a bosom friend with the functionality of the 
National Grand Theater, which perfectly embodies the integration of Oriental culture and modern design.

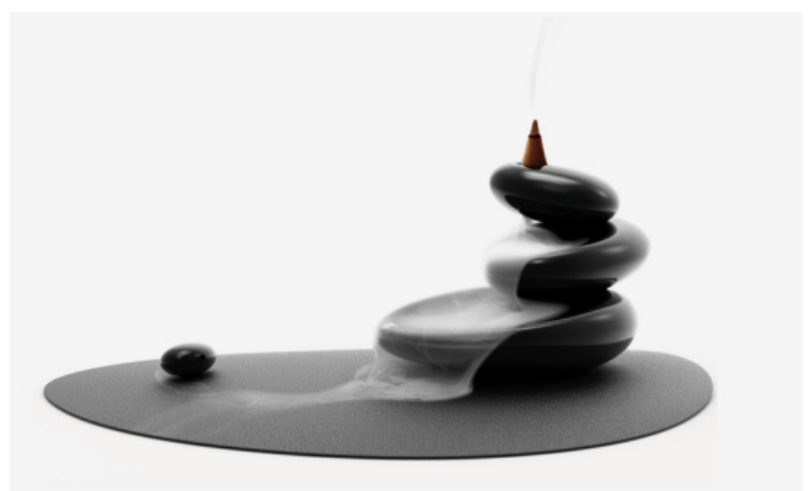

Fig 1. "high mountains and flowing water"fragrant plug. Source: www.lkkdesign.com

Table2. Folklore tourism and the motive factors of product attraction

\begin{tabular}{|c|c|c|c|c|c|c|c|c|c|}
\hline \multicolumn{2}{|c|}{$\begin{array}{l}\text { What is the reason for folk } \\
\text { tourism? }\end{array}$} & \multirow{2}{*}{$\begin{array}{c}\text { sample } \\
\\
50 \\
\end{array}$} & \multirow{2}{*}{$\begin{array}{r}\text { percentage } \\
25.9 \\
\end{array}$} & \multirow{4}{*}{$\begin{array}{l}\text { total } \\
\\
193\end{array}$} & \multicolumn{2}{|c|}{$\begin{array}{l}\text { What is the biggest } \\
\text { attraction for Wen } \\
\text { brigade products to } \\
\text { you? }\end{array}$} & \multirow{2}{*}{$\begin{array}{c}\text { sample } \\
\\
89\end{array}$} & \multirow{2}{*}{$\begin{array}{r}\text { percentage } \\
45.2 \\
\end{array}$} & \multirow{3}{*}{$\begin{array}{c}\text { total } \\
\\
197\end{array}$} \\
\hline \multirow{3}{*}{$\begin{array}{l}\text { Cultural } \\
\text { experience }\end{array}$} & Folk scenery & & & & \multirow{3}{*}{$\begin{array}{l}\text { Cultural } \\
\text { attraction }\end{array}$} & $\begin{array}{l}\text { Handicraft } \\
\text { products }\end{array}$ & & & \\
\hline & $\begin{array}{l}\text { Former } \\
\text { residence of } \\
\text { celebrities }\end{array}$ & 23 & 11.9 & & & $\begin{array}{l}\text { Experience } \\
\text { folk } \\
\text { activities }\end{array}$ & 99 & 50.2 & \\
\hline & $\begin{array}{l}\text { Understanding } \\
\text { folk culture }\end{array}$ & 120 & 62.2 & & & Other & 9 & 45.6 & \\
\hline \multirow{3}{*}{$\begin{array}{l}\text { Recreation } \\
\quad \& \\
\text { Entertainm } \\
\quad \text { ent }\end{array}$} & $\begin{array}{c}\text { Taste special } \\
\text { snacks }\end{array}$ & 110 & 57.3 & \multirow{3}{*}{192} & \multirow{3}{*}{$\begin{array}{l}\text { Business } \\
\text { attraction }\end{array}$} & Folk snacks & 98 & 50.3 & \multirow{3}{*}{195} \\
\hline & $\begin{array}{l}\text { Experience } \\
\text { folk activities }\end{array}$ & 68 & 35.4 & & & $\begin{array}{l}\text { Cultural } \\
\text { tourism } \\
\text { products }\end{array}$ & 87 & 44.6 & \\
\hline & Other & 14 & 7.3 & & & Other & 10 & 5.1 & \\
\hline
\end{tabular}

\subsubsection{Product homogeneity and low end packaging}

In addition, about $70 \%$ of the respondents think that in the same scenic spot or scenic spot, similar cultural tourism products tend to be homogenized seriously and the style is single, as shown in Fig.2. Tourists fail to feel the folk culture of the scenic area through the inherent meaning of the products, and lose the function of cultural tourism products to spread culture, resulting in the situation that the same type of products in the scenic area are stereotyped and lack of creativity. At the same time, the product designers lack in-depth understanding of the scenic area culture and lack of research on tourists' demand. Secondly, during the visit to several folk museums, we found that except for a few medium and high-grade folk gifts and a very small number of folk culture and tourism products, there are few products with local folk cultural characteristics. Most of the packaging design level is relatively ordinary. Some businesses sell cultural and tourism products with ordinary plastic bags instead of packaging or directly without packaging. The homogenization of folk culture and tourism, products and the low-end packaging quality are not conducive to the upgrading of the products, but also lack of certain aesthetic feeling, which may reduce the tourists'

preference for the scenic spot.

\subsubsection{The products are chaotic and of poor quality}

In the investigation of some scenic spots, it is found that in addition to the products with local folk culture, there are also a large number of small commodities unrelated to the scenic area or local folk culture, such as walnut, tea ware, plush toys and so on. These are not only not conducive to the sales of folk cultural tourism products in the scenic area, but also easy to mislead tourists' cognition of folk cultural tourism products. According to the survey, almost all the shops around the scenic spots are selfemployed, and most of the products sold are purchased in batches by the merchants themselves. As a result, the prices of the same kind of products vary from seller to seller, and it is difficult to guarantee the quality of the products. 


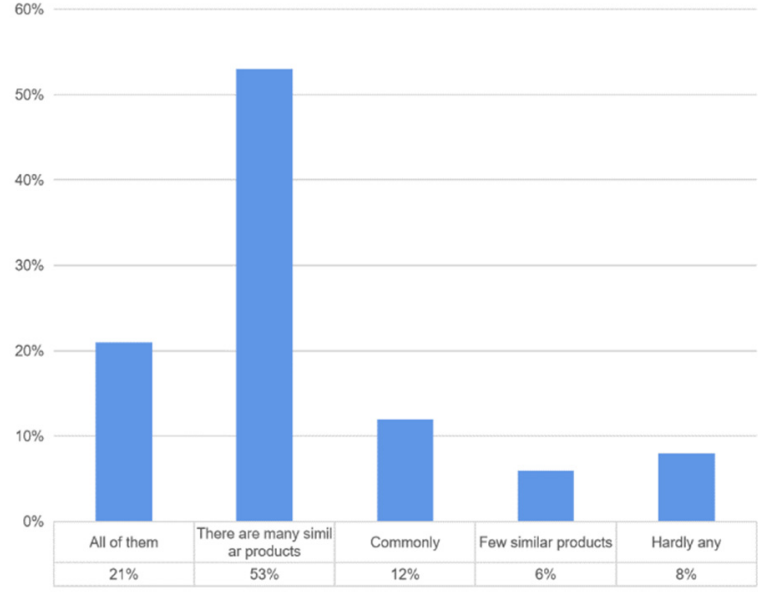

Fig 2. Product homogeneity survey data

\section{Analysis of Jiaodong Folk Culture Tou rism Product Development Strategy}

As an important form of folk tourism in Jiaodong, cultural tourism products are the main means to inherit and develop regional folk culture. According to the survey data, when tourists go to cultural tourist attractions, they expect not only leisure and entertain ment, but also to meet their own cultural needs in the process of tourism. It can provide a theoretical basis for the development of Jiaodong folk culture. ${ }^{[4]}$

\subsection{Orientation of cultural elements}

Cultural elements are a long-lasting spiritual life form of a nation, while folk culture reflects the living habits of people in a region. It mainly includes people's outlook on life, values, aesthetic taste, thinking habits and way of life. It cannot only be expressed through the internal form, but also can carry out cultural exchange and communication with the help of the external form. ${ }^{[5]}$ In order to locate and extract the cultural elements of the folk tourism scenic spots in Jiaodong area, we should first analyses the unique marine folk culture in Jiaodong area. This paper summarizes the traditional folk customs in Jiaodong and the existing folk customs in the scenic spots, and then extracts, designs and applies the cultural elements to the products. Based on the previous investigation, this paper summarizes the elements of folk culture in Jiaodong traditional folk customs and folk scenic spots. In addition, in order to clarify the design and application of folk cultural elements in cultural and tourism products, the author also summarizes the existing cultural and tourism products around Jiaodong folk tourism scenic spots and the folk cultural elements they use. Through the extraction of folk culture elements of relevant scenic spots, it is helpful for designers to deeply think and understand product culture, combined cultural elements, cultural connotation and product functions, and designed cultural tourism products that not only conform to modern people's aesthetic and usage habits, but also reflect traditional folk culture, and reduce the phenomenon of product design homogeneity. ${ }^{[6]}$

\subsection{Cultural tourism brand promotion}

Through the preliminary investigation, it is found that the sales channels of Jiaodong folk tourist attractions and surrounding cultural tourism products are relatively single, the brand value and influence have not yet formed, and the sales mode is mainly passive. Management departments and businesses cannot integrate the product brand, so they cannot adapt to the development of market economy. Brand promotion of Jiaodong folk culture and tourism products should firmly grasp the brand positioning of Jiaodong marine folk culture. Through the integration of marine human customs, characteristic rural household utensils, mountain and sea farming and animal husbandry, and folk handicraft, it will create a "brand with profound traditional culture and rich regional folk characteristics," and attract many tourists who want to experience the traditional folk culture. The brand image of folk culture should be established in the hearts of tourists or potential tourists. When tourists have psychological needs for tourism products, they can associate with the related folk culture and tourism products. Folk culture and tourism brands should be developed based on existing or developing tourism cultural products, integrate similar cultural products, and from cultural and tourism brands with themes, systematization and serialization, and can reflect the unique cultural temperament of various regions in Jiaodong.

\section{Conclusion}

Jiaodong traditional marine folk culture as the core of Jiaodong folk culture, should grasp the marine cultural customs, mountain and sea farming, folk crafts and other elements, and carry out the development and promotion of related cultural tourism products. This paper takes the traditional folk culture and tourism products in Jiaodong as the research object, analyzes the current situation and existing problems of folk culture and tourism products in Jiaodong from the perspectives of practicality, creativity, culture and surrounding environment of the existing folk culture and tourism products in Jiaodong, and provides reference for the folk culture and ourism products in Jiaodong from the aspects of cultural elements, cultural connotation and brand promotion. This paper puts forward some opinions on the development of folk culture and tourism products, hoping to provide the relevant theoretical basis for the follow-up research.

\section{Acknowledgments}

This paper is one of the phased achievements of Shandong traditional culture and economic development special project "Research on digital protection and innovation of traditional folk utensils from the perspec tive of Jiaodong marine folk culture" (YJ201911085)

\section{References}

1. Wang Hu. History of design: a study of traditional 
Chinese design ideas [M]. Nanjing: Jiangsu fine arts publishing house, 2010.

2. Liu Chunlei, Wang Lan, Li Na. Innovative redesign of Shenyang tourist souvenirs from the perspective of cultural identity $[\mathrm{J}]$. Packaging engineering, 2016 (4): 42-46.

3. Dong min, Liu Wei, Lu Bowen. Research on cultural and creative product design based on the history and culture of Shenyang Forbidden City [J]. Packaging engineering, 2016 (4): 11-16.

4. Yin Jinhai, Gao Yuchen, Li Shuyu. Research on creative product design with Manqing cultural characteristics in Shenyang $[\mathrm{J}]$. Packaging engineering, 2016 (4): 33-37.

5. Liao Renjing, Li Qian, Zhang Jie, et al. A study on the tourists' perception of the authenticity of urban historical blocks: a case study of Nanjing Confucius Temple [J]. Journal of tourism, 2009 (1): 55-60.

6. Yang Yi. Research and Analysis on integrating cultural elements into creative product design [J]. Journal of Hubei Academy of fine arts, 2013. (2): 7578. 